\title{
Powerful remains: the continuing presence of victims of the Khmer Rouge regime in today's Cambodia
}

Helen Jarvis Permanent People's Tribunal, UNESCO's

Memory of the World Programme

helenjarvis@online.com.kh

\begin{abstract}
The Khmer Rouge forbade the conduct of any funeral rites at the time of the death of the estimated two million people who perished during their rule (1975-79). Since then, however, memorials have been erected and commemorative ceremonies performed, both public and private, especially at former execution sites, known widely as 'the killing fields'. The physical remains themselves, as well as images of skulls and the haunting photographs of prisoners destined for execution, have come to serve as iconic representations of that tragic period in Cambodian history and have been deployed in contested interpretations of the regime and its overthrow.
\end{abstract}

Key words: Cambodia, Khmer Rouge, memorialisation, Extraordinary Chambers in the Courts of Cambodia, dark tourism

\section{Introduction}

A photograph of a human skull, or of hundreds of skulls reverently arranged in a memorial, has become the iconic representation of Cambodia. Since the overthrow of the Khmer Rouge regime on 7 January 1979, book covers, film posters, tourist brochures, maps and sign boards, as well as numerous original works of art, have featured such images of the remains of its victims, often coupled with the haunting term 'the killing fields', as well as 'mug shots' of prisoners destined for execution.

Early examples on book covers include the first edition of Ben Kiernan's seminal work How Pol Pot Came to Power, published in 1985, on which the map of Cambodia morphs into the shape of a human skull and Cambodia 1975-1978: Rendezvous with Death, edited by Karl D. Jackson and published in 1989, which shows a black-and-white photograph of blindfolded skulls and bound bones laid on the edge of a grave. The trope continues in this century: in 2004, on the cover of Getting Away with Genocide? Elusive Justice and the Khmer Rouge Tribunal written by this author and Tom Fawthrop; and as recently as 2014 in Michelle Caswell's Archiving the Unspeakable: Silence, Memory, and the Photographic Record in Cambodia and on UNESCO's web site for Memory of the World. ${ }^{1}$ 
To reflect on how the remains of the Khmer Rouge's victims have been treated and how they are viewed both by Cambodians and foreigners, I examine the offi$\mathrm{cial} /$ national/public narratives alongside sometimes quite different unofficial/local/ private narratives as they have developed over the past thirty-five years.

For the purposes of this article, I have extended the term 'remains' beyond physical bones or ashes to include photographs and various artistic representations of those physical remains as well as the names of the victims, providing a wider frame through which to view and assess their power. Appearing on an almost daily basis, hauntingly ever-present, emotionally affective and deployed for various political, judicial or ethical purposes, these transportable/transmissible representations provide a vehicle for the remains to emit a continuing 'presence' well beyond memorial sites and graves. ${ }^{2}$

\section{Contested interpretations}

The ineluctable link between the graves and the crimes that led to them gives rise to sharply differing attitudes towards the remains found therein and to polemical arguments about their treatment. Attitudes towards the graves reflect the polarised attitudes to the Vietnamese presence in Cambodia after 1979 - seen on the one hand as a force of national liberation from genocide conducted in solidarity with Cambodia, and on the other as an opportunistic invasion and occupation by an historic enemy-neighbour.

The geopolitical underpinnings and the effects of these contested interpretations are the central theme of Getting Away with Genocide? Elusive Justice and the Khmer Rouge Tribunal written by British journalist Tom Fawthrop and myself, whose perspective has derived from research and observations in Cambodia since 1987, principally as Documentation Consultant for Yale University's Cambodia Genocide Program, member of the Secretariat of the Cambodian Government Task Force on the Khmer Rouge Trials, Chief of Public Affairs and Chief of the Victims Support Section of the Extraordinary Chambers in the Courts of Cambodia (ECCC).

\section{Cambodian funerary traditions}

A necessarily brief introduction to Cambodian funerary traditions may elucidate some aspects of this discussion. As my own research and experience in Cambodia on this issue have related mainly to the public narrative, I wish to acknowledge my reliance on important insights into private and traditional narratives by French anthropologist Anne Yvonne Guillou, drawing not only on her direct observations and interviews from 2006 but also those by the Cambodian historical anthropologist Ang Choulean and French scholars from earlier times. ${ }^{3}$

In the traditions of Khmers, Cambodia's majority ethnic group, the bodies of deceased persons are nearly always cremated in a ceremony performed by Buddhist monks and lay preachers. The bone fragments remaining after the cremation are normally collected by the family and placed inside an urn placed on an 


\section{Helen Jarvis}

altar inside a house or in a stupa (Buddhist shrine). The remaining ashes may be ceremonially scattered, usually in a river.

Khmer customs and ceremonies surrounding death and funerals also include aspects of pre-Buddhist and animist traditions, including distinctions between treatment accorded the remains of those who have died 'good' or 'bad' deaths (such as through violence). The spirits of deceased persons who were not accorded proper rites may be considered 'lost souls' not yet reincarnated but condemned to wander the earth. Funeral ceremonies do not necessarily involve the physical presence of the dead, and specific rituals are followed in such cases, normally involving pronouncing the name of the deceased. ${ }^{4}$

\section{The remains of the genocide}

During the three years, eight months and twenty days that the Khmer Rouge held power (17 April 1975 to 6 January 1979), it is estimated that around two million people perished, over one quarter of the total population. Some died from brutal torture or execution, others of starvation, overwork and untreated illness. The number of those who perished remains a matter of heated debate, with estimates range from 740,000 to $3,314,000$. Recent studies seem to be converging in an estimation of 'between 1.5 to 2 million'. ${ }^{5}$

Whether or to what extent these deaths are correctly described as 'genocide', the term most widely used in Cambodia, is debated. ${ }^{6}$ But regardless of the legal, scholarly, political or sociological terminology, the legacy of this period still cripples Cambodia.

\section{Mass grave sites}

Despite the atomised state of society and paucity of resources in 1979 and the early 1980s, all over the country, mass graves were located and many remains exhumed. While villagers throughout the provinces gathered bones and skulls in makeshift shrines, the new Government conducted official exhumations to provide evidence of the crimes committed by the Khmer Rouge, especially for presentation to the People's Revolutionary Tribunal held in Phnom Penh in August 1979 (see Forensic Analysis section below).

The best known of these mass graves is Choeung Ek, on the outskirts of Phnom Penh, where it is believed more than 20,000 people, chiefly prisoners from the S-21 security centre known as Tuol Sleng, were killed. Both sites were curated as public memorials in 1979-1980. ${ }^{7}$

Initially, S-21 prisoners who died were buried in and around that complex, but the sheer number of bodies made this impractical to continue and, from 1977 Choeung $\mathrm{Ek}$, a former Chinese cemetery, served as S-21's execution and burial site. Some eighty-nine of the estimated 129 Choeung Ek mass graves from this period were excavated in mid-1980, and the remains of 8,985 victims were exhumed. At Tuol Sleng, several individual and mass graves were found and excavated in and around the prison in the early 1980s, and construction work even today exposes others. ${ }^{8}$ 
Throughout the country during the early 1980s, many exhumations were undertaken by village, district or provincial authorities or unofficially by local people not only to provide evidence of the crimes and to retrieve and display the skulls in acts of commemoration of the deceased but also to find small precious items such as jewellery, money or gold, even gold teeth, that could help the finders rebuild their shattered lives. ${ }^{9}$

An extensive mapping project undertaken during the 1990s by the Cambodian Genocide Program and the Documentation Center of Cambodia (DC-Cam) identified 19,471 mass graves, estimated to contain the remains of more than 1 million people. $^{10}$

In recent years, efforts have been made to identify and rehabilitate mass graves and memorials in conjunction with the Extraordinary Chambers in the Courts of Cambodia (ECCC), a hybrid Cambodian court with international assistance and participation, established in 2006 and still under way at the time of writing. ${ }^{11}$

\section{Memorials}

\section{Tuol Sleng}

Soon after the overthrow of the Khmer Rouge, the first official memorial, the Tuol Sleng Genocide Museum, was established. In 1980, the Choeung Ek Genocidal Center followed, and these two memorials have been continually maintained and used for various memorial activities and exhibitions while also becoming primary tourist destinations, each receiving more than 200,000 foreign visitors annually.

Tuol Sleng, a three-storey former high school built in the 1960s, known during the Khmer Rouge regime as S-21, was the apex of the prison system that pervaded the country. So quickly had the prison been abandoned by its fleeing staff that fourteen bloodied bodies were left shackled to iron bed frames, and thousands of documents, including forced 'confessions', lists and biographies of prisoners and staff, prison regulations and photographs of the prisoners were found - showing what had taken place there and providing information about victims that has helped many to discover the fates of their relatives and friends. A dramatic instance was when Civil Party Kim Vun found out that his wife had been held at S-21 and executed from a list shown during his testimony at the ECCC. ${ }^{12}$

The new Government quickly saw the role that S-21 could play in providing graphic evidence of Khmer Rouge crimes. A group of journalists from socialist countries were brought to the site on 25 January 1979 and, within weeks, Vietnamese experts were brought in to oversee the conversion of S-21 into the Tuol Sleng Genocide Museum. The work was led by General Mai Lam, the curator of what was then called the Museum of American War Crimes (now known as the War Remnants Museum) in Ho Chi Minh City. The Tuol Sleng Genocide Museum was inaugurated on 17 April 1980 (the anniversary of the 1975 Khmer Rouge conquest of Phnom Penh), with Ung Pech, a survivor from S-21, appointed as the first director.

The curation strategy was one of minimal intervention, resulting in a stark and confronting site, described by one contemporary observer as 'a museum of 
the Cambodian nightmare' rather than a manicured museum. ${ }^{13}$ Undoubtedly, the curation was inspired by the approach followed in the Holocaust memorials established in former concentration camps in Eastern Europe, which Mai Lam and Ung Pech both visited. Some critics have charged that the display was fabricated to emulate 'the sinister charisma of Auschwitz', ${ }^{14}$ while others go further to cast doubt on the very authenticity of the prison itself. ${ }^{15}$ In response to such questioning, a considered comment was penned by David Chandler in 2013:

The Vietnamese organized S-21 into a museum, using the massive documentation that had survived at the site. Similarly, they turned Choeung Ek into a tourist destination after exhuming thousands of bodies there. In neither case did the Vietnamese invent an institution. Instead, the documents from the S-21 archive, the photographs of prisoners, the interviews that have been conducted with survivors and former workers at the prison and the overwhelming evidence presented at the ECCC trial of Duch [the director of S-21] all convince me that between mid- 1976 and January 7, 1979 S-21 was a completely Cambodian institution, serving the purposes of the terrified and terrifying leaders of a terrified and terrifying Cambodian regime. ${ }^{16}$

Duch himself testified at the ECCC: 'I know the real history. How could anyone say that S-21 was a Vietnamese invention?'17

Recent events illustrate the persistence of such denials as well as the continuing explosiveness of the remains of the Khmer Rouge victims. Recordings of a speech allegedly made by Kem Sokha, a leader of the opposition Cambodian National Rescue Party (CNRP), on 18 May 2013, became an issue in that year's national election campaign. It was reported that in one recording,

Mr. Sokha says: 'The Vietnamese created this place with pictures [of the victims]. If this place is truly Khmer Rouge, they would have knocked it down before they left' and in another: 'Why would the Khmer Rouge be so stupid as to keep Tuol Sleng after killing many people, and keep it as a museum to show tourists? This is just staged. I believe it is staged, isn't it?'18

Although Kem Sokha claimed that the recordings had been fabricated, ${ }^{19}$ Chum Mey, the president of the most prominent Khmer Rouge victims' association (Ksaem Ksan, founded by Civil Parties in the ECCC) demanded an apology and organised demonstrations. ${ }^{20}$ The subsequent outcry resulted in the hurried adoption by the National Assembly on 7 June 2013 of a law banning genocide denial.

'Not recognizing the crimes constitutes an insult to the souls of those who died during the (Khmer Rouge) regime and brings suffering to the surviving family members of the victims,' government lawmaker Cheam Yeap told the National Assembly, saying the law would help people recall their bitter history, bring justice for the victims and help prevent a repetition of the events. ${ }^{21}$

Four S-21 survivors, led by Chum Mey, sued Kem Sokha for defamation in the Phnom Penh Municipal Court. The Cambodia Daily quoted Chum Mey as saying: 
The money is to be used to pay for a Buddhist ceremony to bless the spirits of those who died at the Khmer Rouge security center ... We have suffered pain because we are the victims who were detained and tortured at Tuol Sleng during the Khmer Rouge ... If Mr. Sokha had initially agreed with my plan to just light only three incense sticks to apologize in front of the souls of the victims at Tuol Sleng, then the defamation lawsuit wouldn't have been brought against him. ${ }^{22}$

In Tuol Sleng, the iron bed frames to which 'special' prisoners were shackled are still in situ alongside photographs taken on the day of discovery, and some individual cells have been left intact. Hundreds of photographs are displayed in former cell blocks that had once been classrooms, chiefly depicting mug shots as well as dead and tortured bodies and a few staff activities. These are alongside heaps of prisoner clothing, shackles and iron rods, instruments of torture and paintings and sculptures of the Khmer Rouge leader Pol Pot produced by S-21 prisoners, including paintings of the horrors that took place created by former prisoner Vann Nath after $1979 .^{23}$

In 1987, a wooden stupa was built in one of the courtyards and used as the focal point for ceremonies until it collapsed in the early 2000s. In 2005 a memorial stele was erected in the same location for the same purpose, ${ }^{24}$ and in 2011 a proposal was made by Ksaem Ksan for construction of a new stupa. A simple but imposing design was floated (attributed to S-21 survivor Vann Nath, shortly before he died on 5 September 2011) of a stupa soaring to the top of the buildings, surrounded by circles of plaques inscribed with the names of all the prisoners of S-21. ${ }^{25}$ Reconstructing the stupa was approved in principle by the Royal Government of Cambodia, and funds were pledged by the German Government as part of the ECCC's program of non-judicial measures designed to benefit victims. A memorandum of understanding between the ECCC and the Ministry of Culture and Fine Arts was signed on 10 July 2014, and the new memorial was inaugurated on 26 March 2015 after consultation with various stakeholders on its design, size and location, and whether or not to inscribe victims' names as part of the memorial (see Names of the Victims section below).

The only explicit display of remains included in the Tuol Sleng Genocide Museum provoked passionate controversy. This was the 'map of skulls' - from at least 1980 until 2002 the final exhibit seen by visitors as they left the museum. It comprised 320 skulls forming the outline of Cambodia with major rivers and lakes painted in blood red. ${ }^{26}$

This finale left many visitors in high distress. Paradoxically, it more often provoked criticism of the museum for its lack of respect and sensitivity to both victims and survivors, rather than its intended effect of outrage at the killing and opposition to the continued recognition of the Khmer Rouge as the official representatives of the Cambodian people by the United Nations. In October 1991, the Paris Peace Agreements were signed by the State of Cambodia and the three resistance factions, including the Khmer Rouge. Elections were held in May 1993 and a new constitution was adopted, establishing a constitutional monarchy and reinstating Norodom Sihanouk as King. The following year, the King requested the 


\section{Helen Jarvis}

Government to dismantle the map of skulls at Tuol Sleng and cremate the remains, arguing that this would honour the dead and allow their spirits to be reborn, in accordance with Cambodian Buddhist tradition. ${ }^{27}$

But after the Government acceded to his request the King abruptly announced it would be dropped, 'in response to a plea from the Central Committee of the CPP [to] keep the bones as evidence of the genocidal regime'. ${ }^{28}$ In 2001, Prime Minister Hun Sen said he was willing to hold a national referendum on what to do with the skulls, but only after the conclusion of the trial of former Khmer Rouge senior leaders then being negotiated between the Cambodian Government and the United Nations. In any event, the map was dismantled in a Buddhist ceremony on 10 March 2002, officially announced as necessitated by the deteriorating condition of the skulls, ${ }^{29}$ which were later placed more reverently in a glass case in the same room with regular religious offerings made. It was replaced by a large colour photograph of the map that has not aroused the same opposition.

Tuol Sleng Genocide Museum is owned and managed by the Ministry of Culture and Fine Arts through its Department of Museums. In 2008, the Tuol Sleng Genocide Museum Archives were inscribed on UNESCO's Memory of the World Asia-Pacific regional register and, in 2009, on the international register. ${ }^{30}$

\section{Choeung Ek}

At the time the Choeung Ek mass grave site was opened as a memorial in 1980, the skulls and long bones of some of the 8,985 victims exhumed from eighty-nine of the 129 graves were placed on wooden shelves under cover of simple roofs. By the mid-1980s a number of sign boards had been erected giving details about the exhumation as well as strong political messages and appeals against genocide.

In 1988 a significant memorial stupa was constructed, designed by the Cambodian architect Lim Ourk displaying the thousands of skulls behind glass, as well as some long bones and clothes found in the graves. There is space for prayer and the placing of incense and flowers or wreaths, while one side faces a large field used for remembrance ceremonies. ${ }^{31}$

Memorials have also recently received renewed focus as accountability for the crimes has finally come on to the agenda. On 19 March 2000, as leader of a United Nations delegation negotiating the establishment of the ECCC, Hans Corell, the Under Secretary-General for Legal Affairs, laid a wreath in front of the remains houses in the Choeung Ek stupa, saying: 'We have come here to remember ... the atrocities that visited the people of this country in the '70s. This must not be forgotten ... We can of course all ask ourselves where we were when all this happened. Our hope is that the United Nations today is different from what it was in those days. ${ }^{32}$

A number of memorials were proposed as reparations to the ECCC Trial Chamber on 31 March 2014 by the Civil Party Lead Co-Lawyers and the Victims Support Section. While most are currently pending due to lack of funds, at least one memorial was specified in the Trial Chamber's judgment of 7 August 2014: a modern sculpture by Cambodian-French artist Ing Séra entitled 'For those who are no longer here' to be placed in a public street in Phnom Penh. Further 
memorials in various provinces are among future reparation projects currently under discussion. ${ }^{33}$

\section{Local memorials}

The mapping project carried out in the 1990s by the Cambodia Genocide Program and DC-Cam identified seventy-seven memorials in various provinces. ${ }^{34}$ Most of these were simple wooden structures, resembling shrines or huts, in which several skulls were placed, while others were dedicated spaces in existing buildings such as former prisons. ${ }^{35}$

Many were already dilapidated, while others had entirely disappeared due to ravages of nature. The difficulty of maintaining so many memorials indefinitely was very real, as was anxiety about the wisdom of being seen to maintain them. Reportedly many memorials, as well as documents from Khmer Rouge prisons, became casualties of the complicated political situation surrounding the signing of the Paris Peace Agreements, as custodians of such evidence feared retaliation from the returning Khmer Rouge if identified. ${ }^{36}$ At the same time, Cambodia was undergoing a revival of Buddhist practices and a relaxation of official attitudes towards religion, culminating in the renewed designation in 1989 of Buddhism as Cambodia's state religion. Many remains were moved from individual memorials close to graves onto the sanctified grounds of wats (Buddhist temples). The abandonment of local memorials sometimes coincided with the sale of state land on which memorials had been constructed, as part of Cambodia's turn to a freemarket economy. ${ }^{37}$

A compelling alternate reading of the physical deterioration of the local memorials, by Rachel Hughes and Anne Guillou, is that they may be morphing into traditionally sacred places dedicated to neak $t a$ (local land spirits), in which natural and human-made objects become one and are left to nature. In Guillou's words:

Energy is believed to emanate from the places where powerful neak ta dwell. Such places are said to be 'powerful'... and to be full of 'energy' ... The same energy radiates from some mass graves and killing fields ... Alain Forest argues that the neak ta is a spirit which, for some reason, has not been transformed into the spirit of a dead person sent to the island of the dead, and therefore cannot be reborn. In this way, it is similar (but not identical) to those who have died a bad death. ${ }^{38}$

Hughes argues, 'Given that some genocide memorial sites are also neak ta sites (or occur near to them), it is possible that there has been a transference to the local memorials of cultural understanding and practice that was once proper to neak ta worship'. ${ }^{39}$

Some neak ta were historical personages who died a 'bad' or violent death. Such a transformation may also be happening to the remains of Pol Pot, leader of the Khmer Rouge, who died on 14 April 1998. His body was unceremoniously placed on a pile of discarded furniture and rubber tyres and set alight, and his ashes were placed in a rudimentary memorial shrine. Despite the widespread condemnation 


\section{Helen Jarvis}

of the miseries Pol Pot wrought upon the Cambodian people, his grave attracts many visitors. In 2006 The King Father, Norodom Sihanouk observed in his characteristically ironic style:

Pol Pot (who died quietly in his bed) has become, in his grave in Anlong Veng ${ }^{40}$, a 'saint'. In front of this grave, his compatriots queue every day, lighting candles and incense sticks. Thus, the worshippers of Saint Pol Pot can win the lottery and other gambling games (in casinos or elsewhere). True. ${ }^{41}$

\section{Forensic analysis}

The remains of Khmer Rouge victims at Choeung Ek and Tuol Sleng have undergone several rounds of forensic analysis. At Choeung Ek, immediately after exhumation in 1980, the skulls were reportedly cleaned and a chemical preservative was applied. In 1988-89 a team of forensic scientists from Ho Chi Minh University, led by Professor Quang Quyen, undertook an analysis commissioned by the Phnom Penh Municipality Department of Culture. The skulls were again coated with a preservative, and they were measured and classified by age, sex, ethnicity and, in some cases, cause of death. ${ }^{42}$

In 2002 a preliminary investigation for a forensic study project on skulls from Choeung Ek carried out in collaboration between the Coalition of International Justice and DC-Cam reported that the skulls demonstrated 'blunt-force trauma, sharp-force trauma and gunshot wounds'. ${ }^{43}$ Although originally designed for public exhibition at Tuol Sleng, in deference to sensitivity about exhibiting remains, the skulls and pedestals are currently housed in a separate room at Tuol Sleng. According to the exhibit notes, 'Spaces have been left between slats so that air can reach the skulls, thus allowing the spirits to come and go as they wish'. ${ }^{4}$

In 2006 a study of eighty-five skulls from the stupa at Choeung Ek was carried out by the United States Joint POW/MIA Accounting Command and Cambodia; the report describes a pattern of systematic execution through blows to a specific area on the back of victims' heads. ${ }^{45}$

In 2013 the Cambodian Ministry of Culture and Fine Arts launched a three-year project to preserve and prepare documentation on all the remaining Choeung Ek skulls.

\section{Commemoration ceremonies}

Each year, commemoration ceremonies for the victims of the Khmer Rouge are twice held - one modern, fixed and public at designated memorials (20 May) and one traditional, somewhat movable and oriented to commemoration of one's ancestors (Pchum Ben).

\section{May}

On 18 August 1983 the National Assembly voted to establish 20 May as the date for formal, official commemorations of the victims and, when instituted in 1983, 
this day was named T'veer Chong Kamhaeng - literally the 'Day for Tying Anger'. While often translated into English as 'Day of Hatred', the Khmer words are more accurately rendered as 'Day of Maintaining Rage'. The twentieth of May was commemorated throughout the 1980s and, after a hiatus following the Paris Peace Agreements, was revived in 1999, becoming the 'Day of Paying Tribute to the Spirits of the Deceased'. In 2003 and 2004 it was termed the 'Day of Victory over the Genocidal Regime' before its current manifestation as the 'Day of Remembrance'. ${ }^{46}$ In response to a request by the ECCC's Co-Lead Lawyers for Civil Parties, in June 2013 a National Day of Remembrance was endorsed as reparation by the Trial Chamber. ${ }^{47}$ The Government informed the Court that it will designate 20 May as an annual official public holiday. ${ }^{48}$

Every year survivors and their descendants flock to Choeung Ek to attend solemn ceremonies, officially organised by the Phnom Penh Municipality and usually presided over by the Governor of Phnom Penh, while similar events are held in some other provincial capitals. At Choeung Ek the program features Buddhist prayers, short speeches, songs and a dramatic pageant re-enacting Khmer Rouge crimes and their overthrow by victorious Cambodian soldiers. Dignitaries, dressed in traditional mourning colours of black and white, remove their shoes and ascend the steps of the stupa to place incense and flower offerings to the spirits of the victims whose skulls are displayed on shelves, with the glass doors open. ${ }^{49}$

In spite of the recognition of Khmer Rouge crimes by all political parties and their asserted commitment to national reconciliation, the non-government parties have shown little interest in what they see less as a national day of mourning than an event promoting the ruling CPP and prefer to hold their own commemoration ceremonies on 17 April, the date on which Phnom Penh fell to the Khmer Rouge.

\section{Pchum Ben}

Pchum Ben is a fifteen-day festival in September to October during the lunar month of photrobot, the traditional period for mourning and making offerings to transfer merit to the dead, especially one's own ancestors. Families visit different wats during Pchum Ben, often in far-flung parts of the country where their ancestors may have died. The ceremonies feature pre-dawn prayers and placing bay ben (rice balls) around the wat, stupas and graves. It is believed that the wandering spirits of those who suffered 'bad' deaths may be afraid to face the light of day, but can receive the offerings in the darkness.

The traditional Pchum Ben ceremonies have heightened significance today. During the Khmer Rouge period, families were dispersed across the country, and bodies of those who died were discarded without ceremony. Most people lost relatives and friends, but do not know where they died, and thus have never been able to perform proper funerals for them. Accordingly, people visit wats near where they suppose their relatives may have perished in hope of connecting with their spirits. These ceremonies are also performed at Choeung Ek and Tuol Sleng. ${ }^{50}$ The Cambodian artist and art historian Ly Daravuth makes the following perceptive observations: 


\section{Helen Jarvis}

The gathering (pchum) of all the bay ben on the last day is a symbolic act of reassembling all that has been scattered - bodies and souls, family members and community - in order to reshape and reenergize the collective. In Pchum Ben, the act of remembering those who have passed away is inclusive ... It is the idea of death itself that is acknowledged, rather than the memory of any particular deceased person. Although people perform the Pchum Ben each year as a way to pay respect to the deceased, it is also a way for them to reaffirm the ethical relationships among the living. The act of gathering together (the act of pchum ben) helps to weave the threads of the social and cultural fabric. ${ }^{51}$

\section{Beyond the bones: representations of the victims}

\section{Names of the victims}

Inscription of the names of victims is a common feature of memorials around the world (except explicitly in memorials to the 'unknown soldier'), and such naming is considered to restore to these victims some dignity and individual identity. ${ }^{52}$ But victims of genocide mostly remain unrecorded and unrecognised, due to their sheer number and the social disorder that necessarily accompanies such catastrophes. In Cambodia, among the 19,471 mass graves recorded, documentation enabling such identification survives only in execution lists at Tuol Sleng, and even there the names of all victims are not known. A concerted effort by the Office of the Co-Prosecutors of the ECCC to combine all the surviving lists and registers of prisoners at S-21, including those sent for execution at Choeung Ek, has resulted in 12,273 names $^{53}$ - perhaps only two-thirds of those who endured that fate. Several documents, including some lists of prisoners from Kraing Ta Chan in Takeo, were also found and are being used as evidence in Case 002/02 being tried at the ECCC in 2015, while I was informed in 1992 that similar documents from the main Siem Reap prison had been recently destroyed, around the time of the Paris Peace Agreements. It would not be too surprising if more lists are eventually located, whether now held in personal or official hands in Cambodia or elsewhere.

In 1995 the Cambodian Genocide Program posted the mug shots from Tuol Sleng on the Internet, giving names and other information where known and appealing to the public to provide them for anyone who was recognised from the photo. ${ }^{54} \mathrm{DC}$-Cam has two projects that relate specifically to the collection of names of victims. Its Family Tracing Project has led on to the more recent Book of Memory project, aiming to collect names of victims and publish them in volumes, each with twenty thousand names. ${ }^{55}$

In 2009, when I was head of the Victims Support Section of the ECCC, I proposed the establishment of a Victims Register. Dr Gregory Stanton was commissioned to prepare an options paper, which highly recommended such a register and exploration of the various options (whose names would be included, who would be responsible for the register, where it would be located). One idea was to house copies in local wats (where they might be known as Kraing Meas or Golden Books), linking the project to Pchum Ben ceremonies. ${ }^{56}$ Unfortunately, funding for this proposed project has not yet eventuated. 
Despite the general long-standing intention to inscribe the names on the proposed new stupa at Tuol Sleng, consistent with the common worldwide practice of recording victims' names on memorials, as well as the Cambodian practice of uttering names of the deceased to represent them in funeral ceremonies, a public controversy recently erupted on the issue. In May 2014, S-21 survivor and President of Ksaem Ksan, Chum Mey, expressed new-found opposition:

Initially he agreed with the inscription ... But after reflection and consultation with the Documentation Center of Cambodia (DC-Cam), he came to oppose the idea, believing that relatives of victims might be upset reading the names of Khmer Rouge cadres along with their family members. His own wife and children were killed.

But Bou Meng, the deputy president of the Victims Association of Democratic Kampuchea, said he would regret if the names were not inscribed: 'I feel disappointed because they just eliminate the names of the victims' ${ }^{57}$

At a stakeholders' meeting on 23 January 2015, following extensive consultation with Civil Parties by the ECCC's Victims Support Section, and with the explicit support of both Bou Meng and Chum Mey, it was finally decided that the names of all prisoners known to have died to Tuol Sleng be inscribed at Choeung Ek or the Prey Sa prison farm known as S-24 on marble plaques surrounding the stupa at Tuol Sleng's new memorial.

\section{Photographs of the victims}

The Tuol Sleng Genocide Museum archive contains photographs of more than 5,000 men, women and children - around one-third of the total number of prisoners incarcerated there and only a handful of whom survived the ordeal. Prisoners were routinely photographed on arrival. Additional photographs were taken of prisoners following death from torture, to prove that they had been 'smashed' (in Khmer Rouge terminology), and a small subset of photographs record staff and their other activities. ${ }^{58}$

Several hundred have been enlarged to A4 size or larger and mounted on display boards in eight former classrooms. The images of the victims arrest the gaze of all visitors and provide the main subject for almost all their reactions and descriptions of Tuol Sleng in social media, journalistic and research accounts alike.

Not infrequently, a Cambodian visitor finds among them the face of a long-lost family member or friend. In such cases the staff of the museum will attempt to find out if there is further information, such as the date of their arrest or execution and their forced 'confessions', and will make a copy of the image for them to take away. Sometimes these photographs are used as surrogates for the physical body of the deceased in funerary rites.

Michele Caswell observes, 'The mug shots, once used as instruments to streamline mass murder, have now come to embody the dead and serve as tools to honor them for the living' ${ }^{59}$ 


\section{Conclusion: dark or dutiful?}

The physical remains of victims of the Khmer Rouge period, together with lists of their names and photographs, have provided critical evidence in the two main trials of Khmer Rouge crimes - the August 1979 People's Revolutionary Tribunal (PRT) and the ongoing ECCC. In the PRT, held within months of the overthrow of the Khmer Rouge, field investigations conducted at seven grave sites in four provinces (Siem Reap, Kampong Cham, Kampong Speu and Kandal) as well as in Phnom Penh provided evidence. ${ }^{60}$

The ECCC's Co-Prosecutors and the Co-Investigating Judges have examined a number of mass grave sites. The written reports and photographs of the graves, as well as the remains and the names and photographs of the victims, are crucial evidence for the Co-Prosecutors and provide support for the testimony of the Civil Parties. ${ }^{61}$ In his trial, Duch frequently tried to deny that certain persons were imprisoned, tortured or executed at S-21 but, when confronted with documentary evidence such as lists of names or photographs, he immediately conceded that the account must be true. If such 'proof' was not provided he continued his denial. For Duch, the paper traces are the only true records. ${ }^{62}$

The mug shots from S-21 and the skulls from the mass graves have become ubiquitous icons, consistently attracting attention and providing the strongest and most enduring images of the Khmer Rouge regime and forming the basis for foreigners' and new generations of Cambodians' understanding.

While Michelle Caswell says that some appear to be drawn to Cambodia precisely because of its reputation for what is known as 'dark' or 'thano' tourism, 'offering up a slice of the extreme for consumption', she goes on to say, ' $t]$ he majority I observed behaved with reverence, quiet reflection, an explicit desire to know more about the Khmer Rouge, and bewilderment at the lack of interpretive information available at the site'. ${ }^{63}$ This echoes observations made a decade earlier by Rachel Hughes, including of visitors' books from 1979-82, when she identified 'the dutiful tourist'. ${ }^{64}$

In very few sites is there sufficient information provided to permit an understanding of the political and historical context, often leaving visitors distressed, horrified and perplexed. Recently some moves have been made to rectify this lack of interpretation. Since 2012 an audio tour in fifteen languages has been offered at Choeung Ek, providing more than one hour of narration, interviews, song and music, while at Tuol Sleng an audio tour is scheduled to be introduced in 2015 . $^{65}$

Hughes has noted the paradox of a memorial site being on the one hand 'a place that illuminates universal humanitarian concerns', exemplified by foreign and United Nations delegations laying wreaths, while on the other hand symbolising 'a specific ... "uncivilised" and even "unspeakable" - horror'. ${ }^{66}$

Some presentations and exhibitions of the photographs from Tuol Sleng have been criticised for just such morbid 'thano' fascination. The US photographers Chris Riley and David Niven, who made a valuable contribution to the preservation of the negatives in the early 1990s, went on to reproduce a number of the images in blown-up art-format prints, exhibiting them in art galleries around the 
world, including the Museum of Modern Art in New York in 1997, with little or no context, and publishing seventy-eight of them in a glossy coffee table book by the art publishers Twin Palms. ${ }^{67}$

Inside Cambodia, over the past fifteen years, the images from Tuol Sleng and Choeung Ek have persistently formed the focus of artistic efforts to recall and memorialise the victims, but also to interrogate and even challenge the notion of victimhood, as in Ly Daravuth's questioning work Messengers from the 2000 show The Legacy of Absence: a Cambodian Story at Reyum in Phnom Penh.

Even as I was writing this article, I came across several very recent works by Cambodian artists interpreting those Tuol Sleng images - a sharp, modern blackand-white graphic displayed in the foyer of the circus tent of Phare Ponleu Selapak; a soft reworking of the often reproduced haunting photograph of Chan Kim Srun holding her newborn baby, which the artist Theam has reverentially placed together with a meditating Buddha image in his private gallery, both in Siem Reap; and in Phnom Penh a collage and hand-coloured stamp on paper by Chath PierSath and a whole exhibition by Em Riem at Chinese House. ${ }^{68}$ Em Riem explains: 'In the peace of mind of my workshop, these faces do not haunt me; I just collect their suffering with love. I tell them: "You can see well that you are not forgotten!" I also tell them: "Each of you appears in the plenitude of your dignity. The numbers that were inflicted on you to deprive you of your human identity now serve to exalt it. ${ }^{69}$

The remains of victims of the Khmer Rouge are a constant presence in Cambodia - as a focus for commemoration and memorialisation; as evidence of the crimes; inspiring artistic works in many different genres; and as instant symbols of the genocide. Their treatment continues to be highly controversial, as discussed in many episodes above, revealing their continuing potency even more than thirtyfive years after the victims died.

\section{Notes}

1 B. Kiernan, How Pol Pot Came to Power (London, Verso, 1985); K. D. Jackson (ed.), Cambodia 1975-1978: Rendezvous with Death (Princeton, Princeton University Press, 1989); T. Fawthrop \& H. Jarvis, Getting Away with Genocide? Elusive Justice and the Khmer Rouge Tribunal (London, Pluto, 2004); M. Caswell, Archiving the Unspeakable: Silence, Memory, and the Photographic Record in Cambodia (Madison, University of Wisconsin Press, 2014); and UNESCO's web site for Memory of the World. URL: www.unesco.org/new/en/communicationand-information/flagship-project-activities/memory-of-the-world/register/ full-list-of-registered-heritage/registered-heritage-page-8/tuol-sleng-genocidemuseum-archives/\#c188357 (accessed 21 March 2015).

2 As argued by Caswell in Archiving the Unspeakable.

3 See especially Anne Y. Guillou, 'An Alternative Memory of the Khmer Rouge Genocide: The Dead of the Mass Graves and the Land Guardian Spirits (neak ta)', South East Asia Research, 20:2 (2012), 207-26.

4 Ibid., 216-18.

5 740,000 asserted in M. Vickery, Cambodia 1975-1992 (Boston, South End, 
1984), p. 18; the Research Committee of the Salvation Front in 1983 claimed 3.314 million and this figure is still used by the Cambodian government; for estimates around 1.7 million see B. Kiernan, The Pol Pot Regime (New Haven, Yale University Press, 1996), p. 458; M. Sliwinski, Le Genocide Khmer Rouge: Une Analyse Démographique (Paris, L'Harmattan, 1995), p. 57; P. Heuveline, 'Between One and Three Million': Towards the Demographic Reconstruction of a Decade of Cambodian History (1970-79), Population Studies, 52:1 (1998), 49-65, 56.

6 For a summary of the arguments see H. Jarvis, 'Cambodian Genocide Overview', Modern Genocide: Understanding Causes and Consequences, ABC-CLIO, 2014. URL: http://moderngenocide.abc-clio.com/Topics/Display/3 (accessed 26 March 2015).

7 R. Hughes, 'Memory and Sovereignty in Post-1979 Cambodia: Choeung Ek and Local Genocide Memorials', in S. Cook (ed.), Genocide in Cambodia and Rwanda: New Perspectives (New Haven, Yale Center for International and Area Studies, 2004), pp. 269-92; R. Hughes, 'Fielding Genocide: Post-1979 Cambodia and the Geopolitics of Memory', PhD dissertation, University of Melbourne, 2006.

8 On 2 June 2000 a grave of eight people was unexpectedly unearthed about two blocks away from the main prison buildings at Tuol Sleng. See H. Jarvis, 'Mapping Cambodia's “Killing Fields", in J. Schofield, W. G. Johnson \& C. M. Beck (eds), Matériel Culture: The Archaeology of 20th Century Conflict (London \& New York, Routledge, 2002), pp. 91-102, 99; and in September 2014 another body was found inside the perimeter fence.

9 Hughes, 'Memory and Sovereignty', Hughes, 'Fielding Genocide'; Guillou, 'Alternative Memory'.

10 Pheng Pong Racy, Phat Kosal, Chhang Youk, Sin Khin \& Ouch Sam-Oeun, Mapping the Killing Fields of Cambodia 1995, 1996, 1997, 1998, 1999, 2000, 2001, 2002, 2003, Phnom Penh, Documentation Center of Cambodia, 26 May 2003. The author was closely involved in initiating this mapping program within the framework of the Cambodian Genocide Program, securing partial funding from the Australian Government and designing and implementing the Cambodian Geographic Database in which to record its results. For more detail see Jarvis, 'Mapping Cambodia's "Killing Fields"', pp. 91-102.

11 See the Extraordinary Chambers in the Courts of Cambodia (ECCC)'s web site. URL: www.eccc.gov.kh; and Fawthrop and Jarvis, Getting Away with Genocide?; for a discussion of victim participation in the ECCC, including the issue of reparations, see H. Jarvis, 'Justice for the Deceased: Victims' Participation in the Extraordinary Chambers in the Courts of Cambodia', Genocide Studies and Prevention, 8:2 (2002), 19-28.

12 J. Freeman, 'Khmer Rouge Court Witness Learns of Wife's Fate', Phnom Penh Post, 23 August 2012, p. 1.

13 D. Hawk, 'Cambodia: A Report from Phnom Penh', New Republic, 15 November 1981, cited in D. Chandler, Voices from S-21: Terror and History in Pol Pot's Secret Prison (Chiang Mai, Silkworm Books, 2000), p. 5.

14 S. Thion, Watching Cambodia: Ten Paths to Enter the Cambodian Tangle (Bangkok, White Lotus, 1993), p. 181. 'In the West, the paradigm of genocide is 
still very much centred on Auschwitz. So true is this that, in an effort to attract part of the sinister charm of Auschwitz, the masters of the new Cambodian regime, in early 1979, commissioned some Vietnamese experts trained in Poland, to refurbish the interrogation centre called Tuol Sleng'. In the same book (p. xix) Thion states that 'a conscious attempt was made to introduce images drawn from the German concentration camps, like the mountain of clothing seen in so many 1945 pictures. Later, some of this reconstructed evidence ... was removed'.

15 'In 1997, when questioned by the journalist Nate Thayer, Pol Pot denied any knowledge of "Tuol Sleng": "I want to tell you - Tuol Sleng was a Vietnamese exhibition. A journalist wrote that. People talk about Tuol Sleng, Tuol Sleng, Tuol Sleng ... When I first heard about Tuol Sleng it was on the Voice of America." Extract taken from Chandler, Voices from S-21, p. 8, citing N. Thayer, 'Day of Reckoning', Far Eastern Economic Review, 13 May 1999. During the Khmer Rouge regime, the prison was known by its code name S-21, not Tuol Sleng.

16 D. Chandler, 'The Effort to Invent S-21 Would Have Been Far Too Costly for the Vietnamese', Searching for the Truth, Magazine of Documentation Center of Cambodia, (Special English Edition, Second Quarter 2013), p. 46.

17 T. Cruvellier, The Master of Confessions: The Making of a Khmer Rouge Torturer (New York, HarperCollins, 2014), p. 210.

18 Eang Mengleng \& Zsombor. Peter, 'Kem Sokha Says S-21 was Vietnamese Conspiracy', Cambodia Daily, 27 May 2013. URL: www.cambodiadaily.com/ archives/kem-sokha-says-s-21-was-vietnamese-conspiracy (accessed 23 March 2015).

19 Chhorn Chansy \& Zsombor. Peter, 'CNRP Accuses Government of Misrepresenting Comments', Cambodia Daily, 30 May 2013. URL: www. cambodiadaily.com/archives/cnrp-accuses-government-of- misrepresentingcomment (accessed 23 March 2015).

20 This resulted in a public schism between S-21 survivors Chum Mey and Bou Meng, who had both previously worked closely together in the establishment of Ksaem Ksan (Victims Association of Democratic Kampuchea). See Meas Sokchea, 'Bou Meng distances victims from scandal', Phnom Penh Post, 4 June 2013. URL: www.phnompenhpost.com/national/bou-meng-distances-victims-scandal (accessed 21 March 2015).

21 Sopheng Cheang, 'Cambodia passes bill against genocide denial', Associated Press, in Northwest Asian Weekly, 15 June - 21 June, 2013, pp. 5, 15. URL: issuu.com/ nwasianweekly/docs/layout25/15 (accessed 23 March 2015).

22 Kuch Naren, 'S-21 Survivor Sues Kem Sokha for Defamation', Cambodia Daily, 15 June 2013. URL: www.cambodiadaily.com/elections/s-21-survivor-sues-kemsokha-for-defamation-31066/ (accessed 12 March 2015).

23 See Vann Nath, A Cambodian Prison Portrait: One Year in the Khmer Rouge's S-21 (Bangkok, White Lotus, 1998).

24 Dates provided by Chhay Visoth, Director of Tuol Sleng Genocide Museum, private email to the author, 28 July 2014.

25 'Proposal by the Ksaem Ksan Victims Association for the Construction of an S-21 Victims Memorial at the Tuol Sleng Museum' (undated but recorded by the ECCC 


\section{Helen Jarvis}

as Document F25.1, English translation placed on the Case File on 1 April 2011).

26 W. Shawcross, The Quality of Mercy: Cambodia, Holocaust and Modern Conscience (Glasgow, Fontana, 1985), p. 44; the number of skulls provided by Chhay Visoth, Director of the Tuol Sleng Genocide Museum, in email correspondence, 28 July 2014.

27 G. Peters, 'Restoration Project Immortalizes Haunting Images of S-21', Cambodia Daily, 12 October 1994, p. 16, cited in Hughes, 'Fielding Genocide', 143.

28 Agence Khmer de Presse, 19 January 1995, p. 2, cited in Hughes 'Fielding Genocide', 148.

29 Hughes, 'Fielding Genocide', 149-50.

30 See UNESCO's web site for Memory of the World. The author was involved in preparing the nomination dossier for the Tuol Sleng Genocide Museum Archive.

31 The Choeung Ek Genocidal Center is under the Municipality of Phnom Penh, although management of the site was contracted to a private company in 2005. Some sharp public opposition was expressed at the time. See Hughes, 'Memory and Sovereignty', p. 274; since then the site has been considerably improved, including a small museum and film screening room, an interpretive audio tour, rest areas and toilet facilities.

32 K. McEvers \& P. Sisovann, 'UN Delegation Lays Wreath at Killing Fields', Cambodia Daily, 20 March 2000.URL: www.cambodiadaily.com/archives/ un\%E2\%80\%88delegation-lays-wreath-at-killing-fields-15801/ (accessed 23 March 2015).

33 ECCC Press Release, 'Wide Ranging Support Secured for the Reparations for Victims of the Khmer Rouge', issued 21 April 2014 with Annex 'Overview of Civil Party Reparation Requests in Case 002/01', 4 April 2014; and ECCC Trial Chamber, Case 002/01 Judgment, 7 August 2014, E313. Séra's original design depicted figures with severed heads and limbs, but he has subsequently modified it in response to criticisms that such treatment would cause further affront to the victims.

34 Racy et al., Mapping the Killing Fields.

35 Fawthrop \& Jarvis, Getting Away with Genocide?, pp. 72-3; Hughes, 'Memory and Sovereignty', p. 277.

36 As reported to the author by local informants interviewed during the mapping project.

37 Guillou, 'Alternative Memory', 214.

38 Ibid., 221-2, based on her own research in Pursat, acknowledging the work of Eveline Porée-Maspero, Ang Choulean, Alain Forest and Francois Bizot.

39 Hughes, 'Fielding Genocide', p. 124.

40 Anlong Veng, a town in in northwest Cambodia, was the final stronghold of the Khmer Rouge.

41 N. Sihanouk, 'Les Ames Errantes des Victimes des Khmers Rouges Polpotiens', Bulletin Mensuel de Documentation, 25 July 2006, cited in Hughes, 'Fielding Genocide', 224.

42 Interview of Quang Quyen by Tom Fawthrop at Choeung Ek Genocide Memorial 
Site, December 1988, cited in Fawthrop \& Jarvis, Getting Away with Genocide?, p. 113.

43 M. Klinkner, 'Forensic Science for Cambodian Justice', International Journal of Transitional Justice, 2 (2008), 227-43, 234.

44 Website: Documentation Center of Cambodia (DC-Cam), URL: www.d.dccam. org/Projects/Forensic_Study/Forensics_Exhibition.htm (accessed 23 March 2015).

45 Klinkner, 'Forensic Science', 234.

46 Fawthrop \& Jarvis, Getting Away with Genocide?, p. 74; For an overview of the origin and development of this anniversary see R. Hughes, 'Remembering May 20 - Day of Anger', Searching for the Truth, magazine of the Documentation Center of Cambodia, 12 December 2000, pp. 39-42.

47 'Overview of Civil Party Reparation Requests in Case 002/01'.

48 Letter from Hing Thoraxy, Secretary of State of the Office of the Council of Ministers to the Lead Co-Lawyers, 11 June 2013.

49 As witnessed on a number of occasions by the author and reported by Seth Mydans, 'Choeung Ek Journal - A Word to the Dead: We've Put the Past to Rest', New York Times (International), 21 May 1999, A4.

50 Hughes, 'Fielding Genocide', 114-16; Guillou reports that the Pchum Ben festival was not re-established after the Khmer Rouge period until the early 1990s. See 'Alternative Memory', 218.

51 L. Daravuth, 'Notes on Pchum Ben: A Working Paper of Recasting Reconciliation through Culture and the Arts', Brandeis University, 2005. URL: www.brandeis. edu/ethics/pdfs/Pchum_Ben.pdf (accessed 23 March 2015).

52 Indeed, the names themselves form the central focus of the Vietnam Veterans Memorial Wall in Washington, DC, designed by Maya Lin, URL: http://thewallusa.com/ (accessed 23 March 2015) and of the 'Naming Memorial' closing event of The Vienna Project, directed by Karen Frostig held on 18 October 2014. URL: www.theviennaproject.org (accessed 10 March 2015).

53 ECCC Trial Chamber, Case of Kaing Guek Eav 001, 18-07-2007, 'Revised S-21 Prisoner List', E68.1, 19 May 2009.

54 See H. Jarvis, in collaboration with N. Cross, 'Documenting the Cambodian Genocide on Multimedia', Mellon Foundation Sawyer Seminar Series, Yale Center for International and Area Studies, 1 October 1998. URL: www.yale.edu/cgp/ publish/documenting.html (accessed 23 March 2015).

55 DC-Cam Work Plan 2013-2014. URL: www.d.dccam.org/Abouts/Annual/pdf/ DC-Cam_2013-2014_Work_Plan.pdf (accessed 23 March 2015).

56 Gregory H. Stanton 'Creation of a Victims Register' (Phnom Penh, Victims Support Section of the ECCC, 2010). See URL: www.genocidewatch.org in 'About Us' section under 'By Dr. Gregory Stanton' (accessed 23 March 2015).

57 P. McPherson, 'Memorial Plan Prompts Debate about Victims and Perpetrators of Genocide', Phnom Penh Post, 9 May 2014; See also K. Naren, 'Survivor against Inscribing Names of All S-21 Victims', Cambodia Daily, 7 May 2014. As alluded to in the quotation from Chum Mey, the majority of victims at Tuol Sleng were themselves Khmer Rouge cadres who had been purged. However, it would be 


\section{Helen Jarvis}

virtually impossible to determine exactly who among them were responsible for killing people or for committing other crimes, and, furthermore, even whether such perpetrators had themselves become victims of incarceration and subsequent execution. Other reasons given to oppose the inscription of names included that this is not part of Cambodian tradition and that it would be unfair to other victims whose names are not known or similarly recognised.

58 Chandler, Voices from S-21; and Caswell, Archiving the Unspeakable, especially Chapter 1 'The Making of Records'.

59 Ibid., p. 121.

60 H. J. De Nike, J. Quigley \& K. J. Robinson (eds), with H. Jarvis \& N. Cross, Genocide in Cambodia: the Documents of the Trial of Pol Pot and Ieng Sary (Philadelphia, University of Pennsylvania Press, 2000).

61 The ECCC uses civil law procedure that permits victims to apply for recognition as Civil Parties in a criminal trial, giving them full rights to legal reparation, testimony and to seek reparation. For more details on victim participation in the ECCC, see H. Jarvis, 'Justice for the Deceased: Victims' Participation in the Extraordinary Chambers in the Courts of Cambodia', Genocide Studies and Prevention, 8:2 (2013), 19-27.

62 See the 'transcripts' of the ECCC Trial Chamber hearings in Case 001. URL: http:// www.eccc.gov.kh/en/case/topic/1 (accessed 23 March 2015); and video recordings of each session; See also URL: www.cambodiatribunal.org/multimedia/case-002trial-footage/ (accessed 19 March 2015), the web site of the Cambodia Tribunal Monitor, and as described dramatically at several places in Cruvellier, Master.

63 Caswell, Archiving the Unspeakable, p. 146; the term 'thanotourism' seems to have been first used by A. V. Seaton in 1996, 'From Thanotopsis to Thanotourism', International Journal of Heritage Studies, 2:4 (1996), 234-44.

64 R. Hughes, 'Dutiful Tourism: Encountering the Cambodian Genocide', Asia Pacific Viewpoint, 49:3 (2008), 318-30.

65 The author has participated as a consultant in the development of content for these two audio tours by Narrowcasters.

66 Hughes, 'Fielding Genocide', 117-18, 151-61.

67 Ibid., 196-214; Caswell, Archiving the Unspeakable, pp. 71-7; C. Riley \& D. Niven, The Killing Fields (Santa Fe, Twin Palms, 1996), which sold for \$200 a copy. Particular criticism focused on the fact that Riley and Niven claimed copyright for the images and reportedly sold a number of prints to US museums.

68 Ben Thynal, 'Time', 2014. Website: Angkor Art Explo, URL: angkorart.weebly. com/cambodian-artists.html (accessed 23 March 2015); Lim Muy Theam, 'Mother and Child', 2014. URL: theamshouse.com/the_story (accessed 23 March 2015); Chath PierSath, 'A Page of an Art Book', collage and hand-coloured stamp on paper, 2013, reproduced on the cover of T. De Langis, J. Strasser, T. Kim \& S. Taing, Like Ghost Changes Body: A Study on the Impact of Forced Marriage on Victims of the Khmer Rouge Regime (Phnom Penh, Transcultural Psychosocial Organisation, 2014); and Em Riem, 'Glorious Numbers' exhibition, reported by Aria Danaparamita, 'On Burlap, Em Riem Paints the Tormented Faces of Tuol Sleng', Cambodia Daily, 20 November 2014. On the opening night young 
Cambodians were seen taking 'selfie' photos of themselves standing in front of the paintings.

69 Notes on Em Riem's 'Glorieux Numeros' exhibition translated from French by the author. 